\title{
Representative Council for Learners' Perspectives on School Financial Management
}

\author{
Zakhele, Dennis Nzuza \\ c/o Newton Pre-Vocational School, P.O. Box 4122, Willowton, Pietermaritzburg, 3200 (South Africa)
}

\begin{abstract}
.
This paper focused on the involvement of representative council for learners in school financial management. The South African Schools Act mandates that learners from grade eight to twelve should be involved in school governing body of a public school however when it comes to school finances such learners are excluded and marginalised. The study was conducted in a rural school in KwaZulu-Natal. This is a qualitative study coached within the critical paradigm that used focus group to generate data. Critical Discourse Analysis was employed to analyse data. The findings of this study suggest that Representative Council for Learners (RCL) are not happy in the manner they are treated when they are part of the School Governing Body (SGB). As participants to the SGB they felt they lost time that should be dedicated to their studies. Learners also felt very strongly that their participation was to rubber stamp what older members of the SGB would have already decided where the learners had been excluded in the decision-making process. Moreover, RCLs suggested that they can make major contributions to the school budget should they be given the opportunity.
\end{abstract}

Keywords: school governing body, representative council for learners, learners' voices, school financial management, school budget

DOI: $10.7176 / \mathrm{JEP} / 11-8-13$

Publication date:March $31^{\text {st }} 2020$

\section{INTRODUCTION AND BACKGROUND TO THE PROBLEM}

During the apartheid era there were eighteen Departments of Education in South Africa that represented the different demarcations of race, provinces and homelands (Sayed, 2002). After 1994, the new Government of National Unity (GNU) amalgamated these into one national and nine provincial, non-discriminatory Departments of Education (now commonly known as Department of Basic Education) for the non-racial South Africa (Sayed, 2002). As part of the transformation process, the GNU immediately introduce laws and policies aimed at transforming the education system to meet the new challenges. Some of these were the Constitution of South Africa Act, 108 of 1996 (Republic of South Africa, 1996-a), the South African Schools Act, 84 of 1996 (Republic of South Africa, 1996-b) and the White paper on Education and Training of 1995 (Republic of South Africa, 1995) which laid the foundations for the integration of schools in South Africa. In terms of South African Schools Act (SASA) all public state schools in South Africa must have democratically elected School Governing Bodies (SGBs) comprising parents, learners, educators, non-teaching staff and school principal. In the past, learners, educators and non-teaching staff were excluded from governance structures. Although parents were involved in school committees, their participation was mere tokenism (Mncube \& Mafora, 2014). In the process of transforming the education system, all stakeholders were considered in the South African laws and policies. The SGB is meant to bring about democratic change that benefits the school, its learners and the community at large. This was motivated by the fact country's move towards practising democratic principles. According to Davies (1999), democracy entails the model that decisions affecting the whole society would be taken by all its members and that they would each have equal rights to take part in such decisions. It is for this reason that Naidoo, Mncube and Potokri (2015) note that democratic principles, school governance and democratic leadership are the pillars for democratic schools.

\section{LITERATURE REVIEW}

Learners are part and parcel of the school system and the system would not have existed if there were no learners in the education system. Mncube (2008) notes that learners constitute a major stakeholder in the schooling system thus they should play a critical role in policy making and its implementation. Harber and Mncube (2012) share that a democratic school should be realised by democratic relationships clearly committed to the values of democracy for education where power over decision-making is shared amongst learners, parents and staff. The scholars mentioned these three stakeholders (learners, parents and school staff), as they form the cornerstone of the School Governing Body (SGB) of every public school. Learners should be able to express themselves freely and should not be victimised by the pressure exerted by adults who would influence their opinions (Nthontho, 2017). A study by Cockburn (2006) found that the learner voice is effective when he or she attends the proposed meetings but is more effective when learners actively shape the agenda and decisions of meetings with their participation. According to Vygotsky (1978) when learners are involved in decision-making forums they are able to learn effectively. Cockburn (2006) devised three definitions of involvement namely: opportunity- where learners are given the opportunity to attend meetings; attendance- where learners take up that opportunity; and engagement- 
whereby learners not merely attend but are able to make an effective contribution. Given the definitions of involvement schools should open space for learners to deliberate during SGB meetings to meet democratic principles. According to SASA it became compulsory for all secondary schools to have a Representative Council for Learners (RCLs) democratically elected by learners at a school. It is these RCLs that in turn elects two learners to represent other learners on the SGB and to take an active role in school governance. RCLs work involves learner participation in decision-making which encompasses all aspects of school life providing space for students to contribute in school structures and mechanisms of the school (Jeruto \& Kiprop, 2011). The emphasis on democratic values in SASA on learner participation in SGB resonates with what Adamsky, Chapman, Froumin and Aspin (1995) have identified as core values that are typical of schools with democratic forms of leadership and management. These core values are namely:

$>$ The schools are capable, democratic and just, affording learners the opportunity to acquire, apply and practice the different kinds of knowledge, skills and attitudes that will prepare them for life.

$>$ The schools actively demonstrate concern for and promote high standards of excellence in all aspects of school life, both at an individual and institutional level.

$>$ The schools expose learners to a humane outlook on life and instil crucial values as an integral part of each individual's personal and social development.

$>$ The schools develop in learners a sense of independence and self-worth as human beings, giving them confidence in their ability to contribute to society in different ways.

$>$ The schools infuse in learners a concern for the cultural and economic enrichment of the surrounding community.

Understanding the above core values suggest the paradigm shift from undemocratic way of life to a democratic one, which is not a social given. This needs to be practised honestly and nurtured for it to succeed. To see a true democratic society, it is for this reason that Carlsie, Jackson and George (2006) suggest that schools should promote inclusion, equity and high expectations for all learners, to have direct social justice education and intervention. In addition, Maitles and Deuchar (2006) hold the view that meaningful student involvement as partners in every aspect of school strengthen their commitment to education and democracy. Implementing collaborative practice in schools creates a synergy and connections that promotes a better decision-making process that is effective. Love and Miller (2003) show that when educators work with students in schools as opposed to working for them, school improvement is meaningful and positive for everyone involved.

According to National Norms and Standards for School Funding (2004), schools receive their allocations based on the learners they have admitted. These are funds that the schools need to manage. Policies and studies reveal that leaners' participation in school governance is critical just as that of the other stakeholders, however, most of the learners are not involved in school financial management. It is against this backdrop that this study sought to explore learners' participation in school financial management decision-making considering that learners are important stakeholders in the school system.

\section{SIGNIFICANCE OF THE STUDY}

As South African is a country on the journey to full democracy this study is of significance to solidify democratic principles in the education system. The findings of this study would inform the school leadership, management and governance of the benefits of involving learners in school financial management. In addition, the findings would be useful in guiding the democratic government in formulating policies that would enhance effective learner involvement in school financial management. Moreover, this study attempts to add to the growing body of knowledge in the South African democratic schooling system.

\section{AIM AND OBJECTIVES OF THE STUDY}

The aim of this study was to explore Representative Council for Learners' perspectives on school financial management and how their involvement can contribute to the financial management system. This aim was encapsulated by the following objectives, namely to

- Conceptualise challenges of learner involvement in school financial management.

- To empower school leadership, management and governance by involving learners in school financial management.

\section{THEORETICAL FRAMEWORK}

Critical theory was employed as the theoretical framework to underpin this study. Critical Theory (CT) aims to achieve emancipation and transformation of individuals and society through human action (Steinberg \& Kincheloe, 2010). Furthermore, CT seeks to emancipate the disempowered, to redress inequality and to promote individual freedoms within a democratic society. This theory enabled the researcher to understand fully how power and dominance is still entrenched in schools when it comes to the issues related to school finances. It is for this reason that CT was employed to give the voiceless learners the voice where they were able to opine concerning their 
opinions being marginalised on school financial matters. In this respect, the study was to initiate the social change in the school setting which came with the implementation of SASA.

\section{RESEARCH METHOD AND DESIGN}

This study is coached within critical paradigm and is qualitative in nature and explores the learners' involvement in school financial management and how their involvement can contribute to the financial management system. The data in this study was generated by means of focus group interviews. The rationale for utilising focus group interviews was to generate in-depth and rich qualitative data from the learners' views concerning their involvement in school financial management (Niewenhuis, 2013). The number of participants in this study was six which is within the standard range out-lined by Babbie (2013). One rural secondary school was purposively selected from KwaZulu-Natal, South Africa in order to hear and understand how the principles of democracy are implemented in terms of involving learners in decision-making that relates to school finances. The six sampled participants who formed the focus group were drawn from current and previous RCL members. Ethical considerations were followed and consent from parents and learners were obtained. The Free Attitude Interview (FAI) was used to generate data. According to Meulenberg-Buskens (2011), FAI may be conducted between two people or in a group and people talk as they would in a normal conversation. Data was captured by the use of an audio recorder and transcribed. To ensure trustworthiness of data generated, a tolerant and conducive environment for the focus group was created.

In analysing the data Critical Discourse Analysis (CDA) was employed. According to Van Dijk (1993), CDA focuses on structures, strategies and properties of text, talk and communication which tend to reproduce existing unequal power relations. The latter may be related to the dominance of top-down approaches found within the environment. In addition, Van Dijk (1995) asserts that the aim of CDA is to enable the voices of the marginalised groups to be heard. Hence, in this study the marginalised group refers to learners who are not involved in school financial management. For this study data was analysed considering learners' voices (talk) and structure (societal environment).

What are the learners' views about their involvement in school financial management?

How can learners' involvement can contribute to school financial management?

\section{FINDINGS AND DISCUSSIONS}

This study seeks to address the questions, what are the learners' views about their involvement in school financial management and how can learners' involvement contribute to school financial management. In an attempt to answer these questions learners from an RCL explained how they feel about being the members of the SGB and the contribution they can bring when to school financial management. There was agreement amongst learners about challenges they have experienced and still experience by being an SGB member. When asked about their experiences they had the following to say, as Lulu explained:

As RCL members we are not treated fairly in the sense that when there is a finance meeting at school we are not being informed, only on the day of the meeting we are called from the classes to attend the meeting. Sharing the same sentiments is Soso, who felt that the school management does not care about the lessons they lose when attending meetings, which has caused a negative impact on their academic progress.

Having finance meetings during school time as it is always a case in this school have made us drop our marks as teachers are not worried about SGB they have work to cover as it was the case when a test was written and we were in the meeting hence we were not offered another chance to write that test.

In addition, Nana felt very bad and desponded about the manner in which the school treats them when it comes to attending SGB meetings.

Can you image studying hard for a test only to find that you cannot write it because you have to attend a meeting that you were not informed about?

Furthermore, learners felt they are called to the meeting to rubber stamp what has been decided. As Jomo had the following to say:

The worst part is we lose the taught time and you get to the meeting to be told that the decision that you came for has been finalised, like the case when we were told about the company that had to come and cut grass in the school and we were told about that without our views heard.

The lament of RCL members about the time they spend in meetings whilst they should be in classes learning is shared by Spaull (2015) who illustrates how low quality education becomes a poverty trap due to wasted learning time and incomplete curriculum coverage. Whilst Jasson, Lawrence and Grant (2010) posit that resilient schools are those that characterised by a sense of pride in their teaching and learning, good attendance and punctuality on the part of the educators and learners contribute as much as the efficient use of education time.

Similarly, Lulu added:

The other day we saw people coming to fit and replace windowpanes in the school and they stayed for weeks, us as RCLs did not know when were they were assigned this work and other learners were asking 
us about this tender whereas we knew nothing about it, this was embarrassing.

When Lulu was sharing the above incident, Soso remembered more about that company and echoed the following: When they were issues of paying the same company that was fixing the windowpanes we were called to an urgent meeting and we did not even know what was going on but we were asked to respond if their work was of good standard.

What the learners expressed is contrary to their roles as members of the SGB. Such is also confirmed by Roos (2009) who expressed that all governors are elected on a constituency basis and once elected, they all are equal governors and have a responsibility to govern the school within the framework provided by the schools' act. In addition, Bessong, Mashau and Mulaudzi (2016) opine that learner involvement in SGB equip them with leadership skills and provide the necessary space for the learners in a democratic society. Carr (2005) postulates that schools should be the ones that uphold democratic values and be responsible for imparting democratic norms. Training in school financial management should be provided to learners for them to be effective participants. However, the learners have not been given any of this training as Buyiswa had the following to say:

Sir, in this school we have never had any training on school financial management maybe that training is for mature people like teachers not us.

Adding to that was Babo, when he uttered the following

It could be that we are seen to be too young to be involved in school financial management whereas we understand many aspects when it comes to managing finances as we are matured enough to manage our own monies.

What the RCL members expressed is collaborated by Mestry (2004) who posits that SGB members lack financial management training combined with lack of collaboration between the school principal and the members of the SGBs. The findings of this paper suggest that learners felt that they were window dressing as they had not fully participated in school financial management. This paper correlates with a study by Bessong, et al., (2016) which found that learners were required for tokenistic participation in SGB as they were regarded as not ready to share the school space as equal decision-making partners.

Learners were not only opposing what was happening with regards to school financial management, but also felt they could positively assist with contributions to the school in how finances can be managed. Their contributions were noted in the following utterances as Jomo had the following to say:

I feel that as I am studying accounting at the school I, can assist in compiling a school budget and that can save the school large sum of money that it pays bookkeepers.

Lulu shared the following:

My father runs a big supermarket and various shops around this area, myself together with my mother are responsible for doing my family business budget and that's the reason I came to this school to learn accounting and business studies. Therefore, I know exactly how to do budget. With my experience I can easily help our school.

Furthermore, Buyiswa echoed:

If community members who come and use our school can be asked at least to pay by cutting the school grass that can save the school a lot of money rather than employing companies to cut the grass.

From the comments expressed by the RCL members, schools lack the experience to compile budgets, the members feel they can contribute their expertise to the school financial management to bring the budget to acceptable standards. The lack of budgeting in schools is also cited by Xaba (2011) where most participants were frustrated and open about the reason for poor school financial management as being mainly due to unavailable skills and knowledge in compiling school budget and accounting.

\section{CONCLUSION}

The accounts from this study have shown that RCL members are not happy in the manner SGBs are created and implemented in schools, where the learners' authentic rights to education as well as their democratic rights are marginalised. It is clear that RCL members clearly understand school financial management and they demonstrated their own knowledge and skills that they could be utilised to assist the SGB in drawing school budgets and save the school finances. Suggestion are that learners must be fully involved in school financial management and their voices heard for the moulding of future leaders.

\section{REFERENCES}

Adamsky, A. I., Chapman, D. J., Froumin, I. D., \& Aspin, D. N. (1995). Democratic Values in Russian Education 1955-93: An Analytical Review of the Cultural and Historical Background to Reform. Creating and Managing the Democratic School, 86-99.

Babbie, E. (2013). The Practice of Social Research 13 th (Ed.). International Edition: Wadsworth Cengage Learning. Bessong, R., Mashau, T., \& Mulaudzi, P. (2016). Learners as Education Stakeholders: Do They Form Part of Decision-making in South African Schools? International Journal of Educational Sciences, 15(3), 416-423. 
Carlisle, L. R., Jackson, B. W., \& George, A. (2006). Principles of Social Justice Education: The Social Justice Education in Schools Project. Equity \& Excellence in Education, 39(1), 55-64.

Carr, I. (2005). From Policy to Praxis: A Study of the Implementation of Representative Council of Learners in the Western Cape, from 1997 to 2003. PhD Thesis, Unpublished. South Africa: University of Western Cape.

Davies, P. (1999). What is Evidence-based Education?. British journal of Educational Studies, 47(2), 108-121.

Jeruto, T. B., \& Kiprop, C. J. (2011). Extent of Student Participation in Decision Making in Secondary Schools in Kenya. International Journal of Humanities and Social Science, 1(21), 92-99.

Jasson, A., Lawrence, G., \& Grant, C. (2010). Resilient KwaZulu-Natal Schools: An Ethics of care. Southern African Review of Education with Education with Production, 16(2), 81-99.

Love, R., \& Miller, M. (2003). Increasing Student Participation in Self Governance: A Comparison of Graduate and Undergraduate Student Perceptions. College Student Journal, 37(4).

Mestry, R. (2004). Financial Accountability: The Principal or the School Governing Body? South African Journal of Education, 24(2), 126-132.

Meulenberg-Buskens, I. (2011). Free Attitude Interview Technique. London: Unpublished notes.

Mncube, V. (2008). Democratisation of education in South Africa: Issues of Social Justice and the Voice of Learners? South African Journal of Education, 28(1), 77-90.

Mncube, V., \& Harber, C. (2012). The Dynamics of Violence in South African Schools: Draft Report. Unpublished Report. University of South Africa: Pretoria.

Mncube, V., \& Mafora, P. (2014). Devolution of Power in South African Education: Is Democracy Being Served? International Journal of Educational Sciences, 7(1), 109- 117.

Naidoo, R., Mncube, V., \& Potokri, O. C. (2015). Leadership role of School Principals in Democratic Schools in South Africa: Case studies of Two Schools. Journal of Social Sciences, 43(3), 319-328.

Niewenhuis, J. (2013). First Steps in Research. Pretoria: Van Schaik Publishers.

Nthontho, M. (2017). Children as Stakeholders in Education: Does their Voice Matter? South African Journal of Childhood Education, 7(1), 1-7.

Republic of South Africa. (1995). White paper on Education and Training of 1995. Pretoria: Government Printers.

Republic of South Africa. (1996a.). Constitution of the Republic of South Africa, 108 of 1996. Pretoria: Government Printers.

Republic of South Africa. (1996c.). South African Schools Act, 84 of 1996. Pretoria: Government Printers.

Republic of South Africa. (2004). National Norms and Standards for School funding. Pretoria: Government Printers

Roos, C. (2009). Public School Governance in South Africa. Department of Basic Education, 57-60.

Sayed, Y. (2002). Democratising Education in in a Decentralised System: South African Policy and Practice. Journal of Comparative and International Education, 32(1), 35- 46.

Spaull, N. (2015). Schooling in South Africa: How Low-Quality Education Becomes a Poverty Trap. South African Child Gauge, 12, 34-41.

Steinberg, S. R., \& Kincheloe, J. L. (2010). Power, Emancipation, and Complexity: Employing Critical Theory. Power and Education, 2(2), 140-151.

Van Dijk, T. A. (1993). Principles of Critical Discourse Analysis. Discourse \& Society, 4(2), 249-283.

Van Dijk, T. A. (1995). Aims of Critical Discourse Analysis. Japanese Discourse, 1(1), 17- 28.

Vygotsky, L. (1978). Interaction Between Learning and Development. Readings on the Development of Children, 23(3), 34-41.

Xaba, M., I. (2011). The Possible Cause of School Governance Challenges. South African Journal of Education, 31, 201-211. 